\title{
Screening of Phyllosphere Yeast of Rice for the Production Enzymes and Solubilisation of Minerals
}

\author{
M. Jeyashri*, M. Gomathy, K.G. Sabarinathan, R. Subhashini and S. Suresh
}

AC \& RI, Tamil Nadu Agricultural University, Madurai, India

*Corresponding author

\section{A B S T R A C T}

\section{Keywords \\ Phyllosphere, \\ Yeast, Rice, Growth promoting substances \\ Article Info \\ Accepted: \\ 07 July 2019 \\ Available Online: \\ 10 August 2019}

Rice leaf samples were collected at different critical stages from different places of Tuticorin district for isolation of yeast. Leaf samples were collected and imprinted in various medium viz., Sabourauds dextrose agar, Yeast extract Malt extract, Czapek Dox agar, Yeast extract peptone dextrose agar and Potato dextrose agar. Plates were incubated for 24 hours and observed for yeast population. The yeast colonies were dull white to white in colour, a few colonies were pigmented. Cells were oval to round in shape. Biochemical characterization tests were carried out and the yeast isolates were tested for enzyme production and mineral solubilisation.

\section{Introduction}

All aerial plant surfaces are inhabited by diverse assemblages of microorganisms that have profound effects on plant health and impact on ecosystem and agricultural functions. This environment is usually named as phylloplane or phyllosphere (Slavikova et al., 2009). A variety of bacteria, yeasts and filamentous fungi have been isolated from the phyllosphere of several plant species. Microbes residing in the phyllosphere can have various life styles and modes of interaction with the host, being neutral residents, latent pathogens, or plant-health and growth promoters (Kai Wang et al., 2016). In the phylloplane, the growth of microorganisms is dependent on nutrients from plant metabolites that are secreted to the phylloplane or on compounds in materials from external sources that drop on the plant surface. The phytohormones Indole Acetic Acid (IAA) and Gibberellic Acid (GA) are synthesized not only by plants, but also by many microorganisms. Microbial phytohormones are secondary metabolites, which are non-essential to life, but are involved in competition, defence and dispersal (Betina, 1995; Fox and Howlett, 2008).

Exudations are nothing but secretions of living plants, which contain simple sugars, organic acids and other easily utilized compounds which are the main nutrient source for such 
epiphytic yeasts. The yeasts from plant leaves belong to both ascomycete and basidiomycete species.

Anamorphic basidiomycete yeasts are known to dominate in plant phyllosphere filobasidiales and tremellales yeasts of the genus Cryptococcus, as well as red-pigmented yeasts Rhodotorula and Sporobolomyces, are the most numerous. Some ascomycetous species have also been found such as Debaryomyces hansenii, Hanseniaspora uvarum, Kazachstania barnetii, Metschnikowia pulcherima, Metschnikowia reukaufii, Pichia membranifaciens, Saccharomyces cerevisiae and various species of Candida (Kachalkin et al., 2008). The present research work aim to isolate, characterize and screen the yeast from phyllosphere of rice in Tuticorin district.

\section{Materials and Methods}

\section{Collection of samples}

Rice leaf samples were collected at different stages from different locations in Thoothukudi district of Tamil Nadu.

\section{Isolation and purification of yeasts}

Isolation of yeast was carried out using the Sabourauds dextrose agar, Yeast Extract Malt Extract, Czapek Dox agar, Yeast Extract peptone dextrose agar medium with $\mathrm{pH}$ 5.56.0. The samples were surface sterilized using $70 \%$ Ethanol and washed with sterile water and used for isolation. Leaf samples were imprinted and the plates were incubated at room temperature for $24-48 \mathrm{~h}$ at $25^{\circ} \mathrm{C}$. Yeast isolates were selected based on morphology, and purified using Potato dextrose agar medium. The pure cultures of yeast were maintained in Potato dextrose agar slants at $4^{\circ} \mathrm{C}$ and stored at $-20^{\circ} \mathrm{C}$ in $30 \%$ glycerol for further studies.

\section{Morphological and biochemical characterization}

\section{Colony and cell morphology}

The yeast isolates were observed microscopically for the morphological characters.

By culturing on Potato dextrose agar plates, colony morphology was studied. Gram's staining was performed for yeast isolates by following the standard procedure.

\section{IMVIC test (Indole production, Methyl red, Voges Proskauer, Citrate utilization)}

\section{Indole production}

Yeast isolates were inoculated in peptone water and incubated for three days. After incubation Kovack's reagent was added and the results were noted.

\section{Methyl red}

Yeast isolates were inoculated in the broth and incubated for three days. After incubation Methyl red indicator was added and observed the changes in color of methyl red.

\section{Voges Proskauer}

Yeast isolates were inoculated in the broth and incubated for three days. After incubation 12 drops of VP reagent -1 (Napthol solution) and 2-3 drops of VP reagent- II $(40 \% \mathrm{KOH})$ was added and observed for change in colour for the VP test

\section{Citrate utilisation test}

Yeast isolates were streaked on Simmon's citrate agar and incubated for three days. After incubation the colour change was observed and recorded. 


\section{Ammonia production}

Yeast isolates were inoculated in peptone water for the determination of Ammonia production. Then test tubes were incubated for 5 days and the change of colour from yellow to brown by adding Nesseler's reagent is positive for ammonia production. (Nutaratat et al., 2014)

\section{$\mathrm{H}_{2} \mathrm{~S}$ Production}

Yeast isolates were streaked on Triple sugariron agar and incubated for 7days and observed the change of colour from yellow to black.

\section{Enzyme activity}

\section{Amylase test (Buzzini and Martini, 2002)}

Yeast isolates were streaked on starch agar and incubated for $48 \mathrm{~h}$ at $30 \pm 1^{\circ} \mathrm{C}$.

Then Petriplates were flooded with Lugol's iodine solution for $30 \mathrm{sec}$ and drained. Formation of yellow zone around the colonies against dark blue background, indicates the positive starch hydrolysis.

\section{Catalase test (Nutaratat et al., 2014)}

The Yeast isolates were streaked on the Yeast Extract peptone dextrose agar plates and incubated for $48 \mathrm{~h}$ at $30 \pm 1{ }^{\circ} \mathrm{C}$. After incubation few drops of $3 \%$ hydrogen peroxide $\left(\mathrm{H}_{2} \mathrm{O}_{2}\right)$ was added to the grown culture plates and observed for appearance of effervescence which indicates positive for catalase test.

\section{Urease (Ebabhi et al., 2013)}

The Yeast isolates were spot inoculated on the urease media and incubated for three days. After incubation the plates were observed for the change of colour from red to pink.
Pectinase (Aisha, 2016)

The Yeast isolates were spot inoculated on the Vincent's agar medium and incubated for five days.

After incubation the plates were flooded with Iodine solution and observed for the zone formation around the colony

Cellulase (Buzzini and Martini, 2002)

The Yeast isolates were streaked on the CMC agar medium and incubated for 5 days. After incubation plates were flooded with $1 \%$ congo red and discard the congo red. Observed the zone formation around the colony.

\section{Mineral solubilisation}

\section{Phosphate solubilisation}

The phosphate solublization of the yeast isolates were determined by streaking the isolates on the Pikovskaya's medium.

Then plates were incubated at $30 \pm 1{ }^{\circ} \mathrm{C}$ for 3 days. Clear halo zone was observed around the colony.

\section{Potassium solubilisation}

The Potassium solublization of the yeast isolates were determined by Spot inoculation of isolates on the Alexandro medium.

Then plates were incubated at $30 \pm 1^{\circ} \mathrm{C}$ for 3 days. Clear halo zone was observed around the colony.

\section{Results and Discussion}

The study was mainly focused to identify, characterize and screen the yeast isolates for the production of enzymes and other plant growth promoting characteristics. 
Table.1 Colony Morphology and gram staining of the phyllosphere yeast isolates from rice

\begin{tabular}{|c|c|c|c|c|c|c|}
\hline $\begin{array}{c}\text { Yeast } \\
\text { isolates }\end{array}$ & $\begin{array}{c}\text { Gram's } \\
\text { stain }\end{array}$ & Size & Pigment & Form & Margin & Elevation \\
\hline 1 & $++^{\mathrm{ve}}$ & Moderate & Dark pink & Circular & $\begin{array}{l}\text { Sharply } \\
\text { defined }\end{array}$ & $\begin{array}{c}\text { Dome shaped } \\
\text { elevation }\end{array}$ \\
\hline 2 & $++^{\mathrm{ve}}$ & Large & White & Circular & $\begin{array}{l}\text { Sharply } \\
\text { defined }\end{array}$ & Slight elevated \\
\hline 4 & $++^{\mathrm{ve}}$ & Small & Light red & Circular & $\begin{array}{l}\text { Sharply } \\
\text { defined }\end{array}$ & Flat \\
\hline 6 & $+^{\mathrm{ve}}$ & Small & Light red & Circular & $\begin{array}{l}\text { Sharply } \\
\text { defined }\end{array}$ & Flat \\
\hline 9 & $+{ }^{\mathrm{ve}}$ & Small & Dull white & Circular & $\begin{array}{l}\text { Sharply } \\
\text { defined }\end{array}$ & Flat \\
\hline 23 & $+{ }^{\mathrm{ve}}$ & Small & White & Circular & $\begin{array}{l}\text { Sharply } \\
\text { defined }\end{array}$ & Flat \\
\hline 27 & $t^{\mathrm{ve}}$ & Small & Light red & Circular & $\begin{array}{l}\text { Sharply } \\
\text { defined }\end{array}$ & Slight elevated \\
\hline 50 & $++^{\mathrm{ve}}$ & Pin head & Light red & Circular & $\begin{array}{l}\text { Sharply } \\
\text { defined }\end{array}$ & Flat \\
\hline 55 & $+t^{\mathrm{ve}}$ & Pin head & White & Circular & $\begin{array}{l}\text { Sharply } \\
\text { defined }\end{array}$ & Flat \\
\hline 57 & $+{ }^{\mathrm{ve}}$ & Pin head & White & Circular & $\begin{array}{l}\text { Sharply } \\
\text { defined }\end{array}$ & Flat \\
\hline 68 & $+t^{\mathrm{ve}}$ & Pin head & White & Circular & $\begin{array}{l}\text { Sharply } \\
\text { defined }\end{array}$ & Flat \\
\hline 70 & $++^{\mathrm{ve}}$ & Moderate & Red & Circular & $\begin{array}{l}\text { Sharply } \\
\text { defined }\end{array}$ & Slight elevated \\
\hline 71 & $++^{\mathrm{ve}}$ & Small & White & Circular & $\begin{array}{l}\text { Sharply } \\
\text { defined }\end{array}$ & Slight elevated \\
\hline 72 & $++^{\mathrm{ve}}$ & Small & Dull & Circular & $\begin{array}{l}\text { Sharply } \\
\text { defined }\end{array}$ & Slight elevated \\
\hline 75 & $++^{\mathrm{ve}}$ & Small & Light red & Circular & $\begin{array}{l}\text { Sharply } \\
\text { defined }\end{array}$ & Flat \\
\hline 76 & $t^{\mathrm{ve}}$ & Pin head & White & Circular & $\begin{array}{l}\text { Sharply } \\
\text { defined }\end{array}$ & Flat \\
\hline 78 & $+^{\mathrm{ve}}$ & Small & Red & Circular & $\begin{array}{l}\text { Sharply } \\
\text { defined }\end{array}$ & Slight elevated \\
\hline 79 & $++^{\mathrm{ve}}$ & Moderate & Light red & Circular & $\begin{array}{l}\text { Sharply } \\
\text { defined }\end{array}$ & Flat \\
\hline 80 & $t^{\mathrm{ve}}$ & Moderate & Light red & Circular & $\begin{array}{l}\text { Sharply } \\
\text { defined }\end{array}$ & Flat \\
\hline
\end{tabular}


Table.2 Biochemical and enzyme activity of phyllosphere yeast isolates from rice

\begin{tabular}{|c|c|c|c|c|c|c|c|c|}
\hline $\begin{array}{c}\text { Yeast } \\
\text { isolates }\end{array}$ & $\begin{array}{c}\text { IMViC } \\
\text { Test }\end{array}$ & $\begin{array}{l}\text { Ammonia } \\
\text { production }\end{array}$ & $\begin{array}{c}\mathrm{H}_{2} \mathrm{~S} \\
\text { production }\end{array}$ & Amylase & Catalase & Cellulase & Urease & Pectinase \\
\hline 1 & -ve & - ve & - ve & +ve & +ve & +ve & +ve & +ve \\
\hline 2 & -ve & + ve & -ve & -ve & $+\mathrm{ve}$ & - ve & +ve & + ve \\
\hline 4 & -ve & +ve & -ve & -ve & $+\mathrm{ve}$ & -ve & $+\mathrm{ve}$ & +ve \\
\hline 6 & -ve & $+v e$ & -ve & +ve & $+\mathrm{ve}$ & - ve & +ve & +ve \\
\hline 9 & -ve & $+v e$ & -ve & -ve & $+v e$ & -ve & $+v e$ & $+\mathrm{ve}$ \\
\hline 23 & -ve & -ve & -ve & $+v e$ & $+v e$ & -ve & $+v e$ & + ve \\
\hline 27 & -ve & -ve & -ve & +ve & $+\mathrm{ve}$ & +ve & +ve & +ve \\
\hline 38 & -ve & $-v e$ & -ve & +ve & $+v e$ & - ve & +ve & $+v e$ \\
\hline 50 & -ve & +ve & -ve & +ve & $+v e$ & -ve & +ve & $+v e$ \\
\hline 55 & -ve & $+\mathrm{ve}$ & -ve & $+v e$ & $+\mathrm{ve}$ & -ve & -ve & $+\mathrm{ve}$ \\
\hline 57 & -ve & +ve & -ve & +ve & $+\mathrm{ve}$ & -ve & -ve & +ve \\
\hline 68 & -ve & $+v e$ & - ve & +ve & -ve & -ve & -ve & $+v e$ \\
\hline 70 & -ve & $+v e$ & -ve & $+v e$ & $+v e$ & -ve & $+v e$ & $+v e$ \\
\hline 71 & -ve & -ve & -ve & $+v e$ & -ve & -ve & $+v e$ & $+v e$ \\
\hline 72 & -ve & -ve & -ve & -ve & $+\mathrm{ve}$ & -ve & -ve & $+v e$ \\
\hline 74 & -ve & -ve & -ve & $+v e$ & $+\mathrm{ve}$ & -ve & $+v e$ & +ve \\
\hline 75 & -ve & +ve & -ve & $+\mathrm{ve}$ & $+v e$ & -ve & +ve & $+\mathrm{ve}$ \\
\hline 76 & -ve & $+v e$ & -ve & +ve & -ve & +ve & $+v e$ & $+\mathrm{ve}$ \\
\hline 78 & -ve & $+\mathrm{ve}$ & -ve & +ve & $+\mathrm{ve}$ & +ve & +ve & +ve \\
\hline 79 & -ve & $+v e$ & -ve & $+v e$ & $+v e$ & $+v e$ & $+v e$ & $+v e$ \\
\hline 80 & -ve & $+v e$ & -ve & +ve & $+v e$ & +ve & +ve & $+v e$ \\
\hline
\end{tabular}

Table.3 Mineral solublisation ability of yeast isolates

\begin{tabular}{|c|c|c|}
\hline Yeast isolates & Potassium solubilisation & Phosphate solubilisation \\
\hline $\mathbf{1}$ & $-\mathrm{ve}$ & $+\mathrm{ve}$ \\
\hline $\mathbf{2}$ & $-\mathrm{ve}$ & $-\mathrm{ve}$ \\
\hline $\mathbf{4}$ & $-\mathrm{ve}$ & $+\mathrm{ve}$ \\
\hline $\mathbf{6}$ & $-\mathrm{e}$ & $+\mathrm{ve}$ \\
\hline $\mathbf{9}$ & $-\mathrm{e}$ & $+\mathrm{ve}$ \\
\hline $\mathbf{2 3}$ & $-\mathrm{e}$ & $+\mathrm{e}$ \\
\hline $\mathbf{2 7}$ & $-\mathrm{e}$ & $+\mathrm{ve}$ \\
\hline $\mathbf{3 8}$ & $+\mathrm{e}$ & $+\mathrm{v}$ \\
\hline $\mathbf{5 0}$ & $-\mathrm{e}$ & $+\mathrm{ve}$ \\
\hline $\mathbf{5 5}$ & $+\mathrm{e}$ & $+\mathrm{e}$ \\
\hline $\mathbf{5 7}$ & $+\mathrm{e}$ & $+\mathrm{ve}$ \\
\hline $\mathbf{6 8}$ & $-\mathrm{e}$ & $+\mathrm{ve}$ \\
\hline $\mathbf{7 0}$ & $-\mathrm{e}$ & $+\mathrm{ve}$ \\
\hline $\mathbf{7 1}$ & $+\mathrm{ve}$ & $+\mathrm{ve}$ \\
\hline $\mathbf{7 2}$ & $-\mathrm{ve}$ & $-\mathrm{ve}$ \\
\hline $\mathbf{7 4}$ & $-\mathrm{ve}$ & $-\mathrm{ve}$ \\
\hline $\mathbf{7 5}$ & $+\mathrm{ve}$ & $+\mathrm{ve}$ \\
\hline $\mathbf{7 6}$ & $-\mathrm{ve}$ & $+\mathrm{ve}$ \\
\hline $\mathbf{7 8}$ & $-\mathrm{ve}$ & $+\mathrm{ve}$ \\
\hline $\mathbf{7 9}$ & $-\mathrm{ve}$ & $-\mathrm{ve}$ \\
\hline $\mathbf{8 0}$ & $-\mathrm{ve}$ & $+\mathrm{ve}$ \\
\hline & & \\
\hline
\end{tabular}


Plate.1 Yeast isolates and stained cells
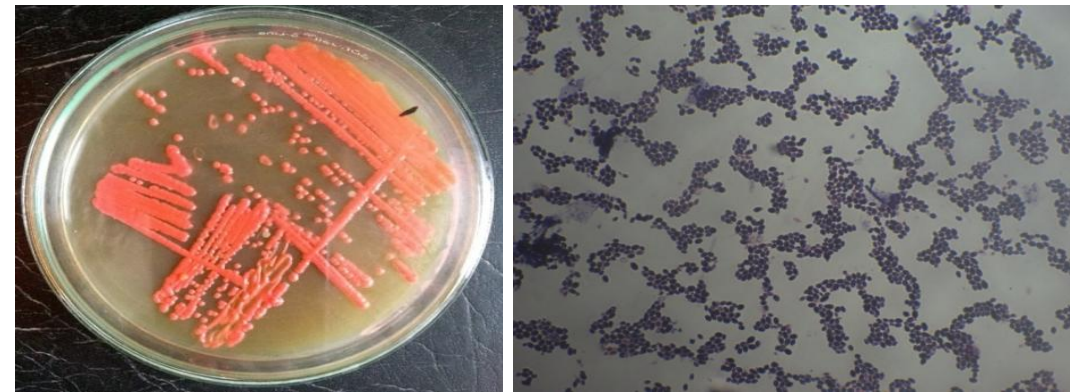

Plate. $2 \mathrm{H}_{2} \mathrm{~S}$ production and Ammonia production of yeast isolates from phyllosphere of rice
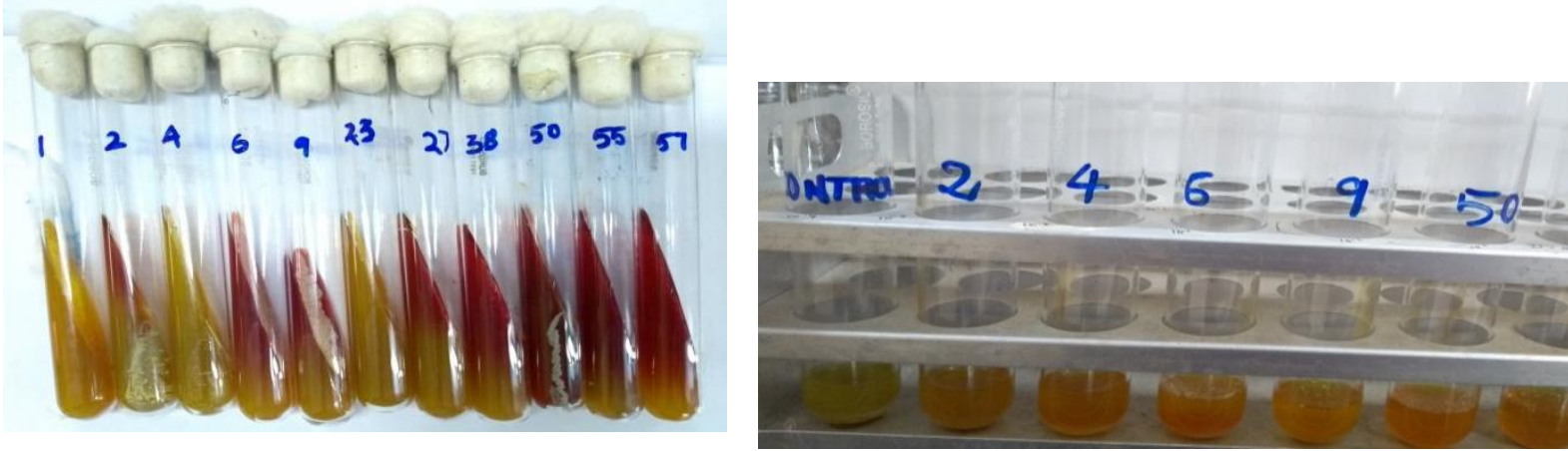

Plate.3 Determination of Enzyme activity using plate assay method
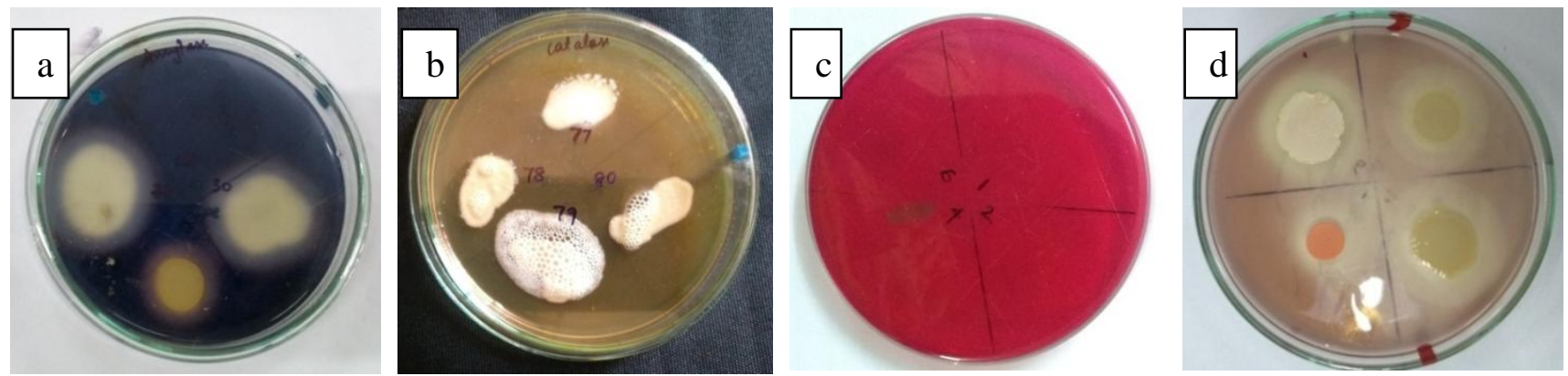

a. Amylase activity, b. Catalase activity, c. Urease activity, d. Pectinase activity

Plate.4 Determination of mineral solubilisation ability of yeast isolates from phyllosphere of rice
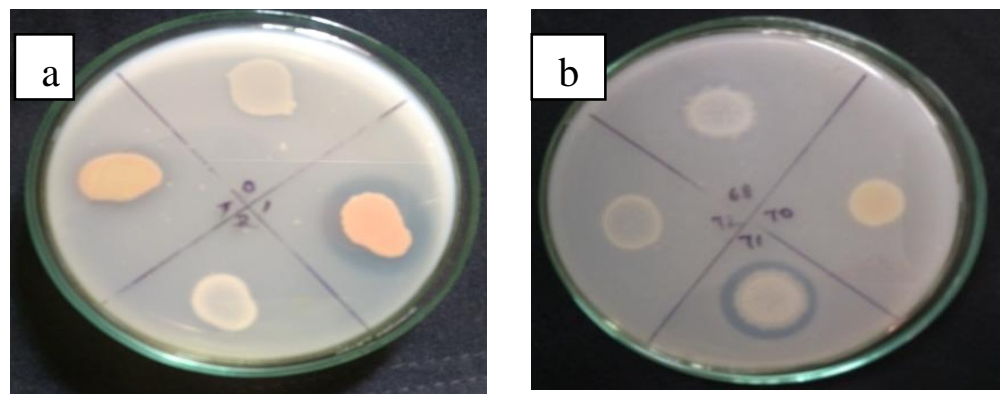

a. Phosphate solubilisation, b. Potassium solubilisation 


\section{Isolation and purification of yeast}

Yeast isolates were isolated from the leaf samples collected from various regions of Tuticorin district using the leaf imprinting technique in various medium. Yeast isolates were obtained and were purified. After purification the isolates were characterized (Table 1; Plate.1). Various studies reported the isolation of yeast from the phyllosphere. About 1035 members of epiphytic and endophytic yeast were isolated earlier from leaves of rice and sugarcane (Nautarat et al., 2014) and also from Vettiver (Limtong et al., 2015), different vegetables (Zhang et al., 2010), different fruit trees (Sláviková et al., 2009).

\section{Characterization of yeast isolates}

The isolates were studied for their morphological and biochemical characteristics.

\section{Morphological and Biochemical characterization}

All the yeast isolates were observed for the morphological characters such as colony size, colour, form, margin and elevation. The colour of the colonies were pink, white, dull white, red, light red and were mostly circular, flat, raised at the centre (Table 1; Plate 1).

Earlier reports of Ghosh et al., (2013) explorated the morphological and biochemical characteristics of yeast isolated from fruit surface of Jamun. Mukadam et al., (2016) reported the isolated yeast produce the pink coloured, gram positive and showed the negative for the urease activity.

\section{Biochemical characterization}

All the isolates showed negative results for the IMViC test and $\mathrm{H}_{2} \mathrm{~S}$ production. Among the isolates, 7 isolates showed negative results for ammonia production (Table 2; Plate 2).

\section{Enzyme activity}

For enzyme activity most of the isolates showed positive results except the cellulase activity. For cellulase activity only 7 isolates showed positive results (Table 2; Plate 3). Carrasco et al., 2016 reported that the most of the psychrotolerant yeast showed the positive for amylase and catalase activity. Fu et al., 2016 isolated the 32 yeasts from the phyllosphere and rhizosphere of Drosera spatulata Lab. and reported 34 strains showed positive for the ammonia production, 29 strains showed positive for the solublisation of tricalcium phosphate, 19 strains showed positive for the cellulase activity, 31 strains showed positive for the catalase activity.

\section{Mineral solublisation}

Except the 4 isolates, all the isolates showed the zone formation around the colony after the incubation which indicates the yeast isolates solublized the tricalcium phosphate.

Only 5 isolates showed the zone formation around the colony after the incubation which indicates the yeast isolates solublize the potassium alumino silicate (Table 3; plate 4).

\section{References}

Aaisha, G. A., and Barate, D. L. (2016). Isolation and identification of pectinolytic bacteria from soil samples of Akola region, India. International Journal of Current Microbiology and Applied Sciences, 5(1), 514-521.

Betina, V. (1995). Differentiation and secondary metabolism in some prokaryotes and fungi. Folia Microbiologica, 40(1), 51-67.

Buzzini, P., and Martini, A. (2002). 
Extracellular enzymatic activity profiles in yeast and yeast- like strains isolated from tropical environments. Journal of Applied Microbiology, 93(6), 10201025.

Carrasco, M., Villarreal, P., Barahona, S., Alcaíno, J., Cifuentes, V., and Baeza, M. (2016). Screening and characterization of amylase and cellulase activities in psychrotolerant yeasts. BMC microbiology, 16(1), 21.

Ebabhi, A. M., Adekunle, A. A., Okunowo, W. O., \&Osuntoki, A. A. (2013).Isolation and characterization of yeast strains from local food crops. Journal of yeast and fungal Research, 4(4), 38-43.

Fox, E. M., and Howlett, B. J. (2008). Secondary metabolism: regulation and role in fungal biology. Current opinion in microbiology, 11(6), 481-487.

Fu, S. F., Sun, P. F., Lu, H. Y., Wei, J. Y., Xiao, H. S., Fang, W. T., and Chou, J. Y. (2016). Plant growth-promoting traits of yeasts isolated from the phyllosphere and rhizosphere of Drosera spatulata Lab. Fungal biology, 120(3), 433-448.

Ghosh, S. K. (2011). Study of yeast flora from fruit of Syzygium cumini (Linn) skeel. Agriculture and Biology Journal of North America, 2(8), 1166-1170.

Kachalkin A V, Glushakova A M, Yurkov A M, and Chernov I Y 2008. Characterization of yeast groupings in the phyllosphere of Sphagnum mosses. Microbiology, 77(4), 474-481.

Limtong, S., Chamnanpa, T., Srisuk, N., and Limtong, P. (2015). Diversity of yeasts in vetiver phylloplane in Thailand and their capability to produce indole-3acetic acid, a plant growth promoter. ICV6 Proc, 1-12.

Mukadam, T. A., Punjabi, K., Deshpande, S. D., Vaidya, S. P., and Chowdhary, A. S. (2016). Isolation and characterization of bacteria and yeast from Kombucha tea. International Journal of Current Microbiology and Applied Sciences, 5(6), 32-41.

Nutaratat, P., Srisuk, N., Arunrattiyakorn, P., and Limtong, S. (2014). Plant growthpromoting traits of epiphytic and endophytic yeasts isolated from rice and sugar cane leaves in Thailand. Fungal biology, 118(8), 683-694.

SlÁviková, E., Vadkertiová, R., \&Vránová, D. (2009).Yeasts colonizing the leaves of fruit trees. Annals of microbiology, 59(3), 419-424.

Wang K, Sipilä T. P., and Overmyer, K. (2016). The isolation and characterization of resident yeasts from the phylloplane of Arabidopsis thaliana. Scientific reports, 6, 39403.

Zhang, B., Bai, Z., Hoefel, D., Wang, X., Zhang, L., and Li, Z. (2010). Microbial diversity within the phyllosphere of different vegetable species. Current Research, Technology and Education Topics in Applied Microbiology and Microbial Biotechnology, 2, 1067-1077.

\section{How to cite this article:}

Jeyashri, M., M. Gomathy, K.G. Sabarinathan, R. Subhashini and Suresh, S. 2019. Screening of Phyllosphere Yeast of Rice for the Production Enzymes and Solubilisation of Minerals. Int.J.Curr.Microbiol.App.Sci. 8(08): 465-472. doi: https://doi.org/10.20546/ijcmas.2019.808.053 